\title{
Divergent gas-exchange and chlorophyll fluorescence in F1 hybrids driving habitat differentiation compared to their parents in Buddleja
}

Weichang Gong ( $\sim$ gongweichang2008@163.com )

Honghe University https://orcid.org/0000-0002-0390-3569

\section{Yaqing Chen}

Honghe University

Jian Wang

Honghe University

Han Yuan

Honghe University

Research article

Keywords: Buddleja, F1 Hybrid, Stoichiometry, Photosynthesis, Chlorophyll fluorescence

Posted Date: September 26th, 2019

DOI: https://doi.org/10.21203/rs.2.15229/v1

License: (c) (i) This work is licensed under a Creative Commons Attribution 4.0 International License.

Read Full License 


\section{Abstract}

Background Inter-specific hybridizations were common and can easily take place in Buddleja, and it was an important way for evolution and rapid speciation. The F1 hybrid in this study was a newly identified inter-specific hybridization between B. crispa and B. offic inalis in Sino-Himalayan region. In the natural hybrid zones, F1 hybrids always occupy different habitats from their parents. The objective of this study was to explore environmental acclimatization of F1 hybrids and their parents at physiological and biochemical levels.

Results The results showed that F1 hybrids performed as an intermediate in adaptation to their parents, with divergent gas-exchange and chlorophyll fluorescence features. F1 hybrids showed the parallel light compensation point and light saturation point with their parents, but low utilization efficiency to low-light density. They synthesized the greatest total chlorophyll content $(10.41 \pm 0.56 \mathrm{mg} \cdot \mathrm{g}-1)$ in leaves than their parents. During the diurnal variation of photosynthesis, F1 hybrids markedly decreased and preserved the stomatal conductance and leaf transpiration rate at a low level. However, they kept high carbon assimilation rate and water-use efficiency with markedly increased vapor pressure deficit. In F1 hybrids, the maximum net photosynthetic rate, maximum water-use efficiency and maximum vapor pressure deficit were $10.48 \pm 0.50 \mathrm{mmol} \mathrm{CO} 2 \cdot \mathrm{mmol}-1$ photo, $21.52 \pm 2.20 \mu \mathrm{mol} \cdot \mathrm{mmol}-1$ and $4.18 \pm$ $0.55 \mathrm{kPa}$, respectively. In addition, all Buddleja species performed well and grow healthy with high level of the maximum photochemical efficiency of PSII and low non-photochemical quenching, $0.83 \pm 0.004$ $0.85 \pm 0.004$, and $1.22 \pm 0.15-1.97 \pm 0.08$, respectively. In F1 hybrids, they showed great photochemical

activity compared to their parental species with high photochemical quenching. Furthermore, the effective quantum yield and electron transport rate presented a similar behavior.

Conclusions The results indicated that $\mathrm{F} 1$ hybrids have great photochemical activities and growth acclimatization compared to their parents. Associated with the growth performance of F1 hybrids in the homogenous garden, our results suggested that the divergent gas-exchange and chlorophyll fluorescence patterns may facilitate F1 hybrids to respond to different habitats, and to improve growth performance.

\section{Background}

Natural hybridization and gene introgression is widespread in angiosperms. It is a potentially creative evolutionary process and generating adaptive variations [1-3]. Species-specific morphological or physiological traits can assist plants to adjust to different ecological environments [4].

Natural hybrids usually present unique combination of morphology that differs with those in their parents $[2,3]$. These hybrids are usually intermediate to their parents in morphology, and have different ecological fitness [1-3]. For example, the hybrids in Cucumis showed divergent phenotypes to respond to low-light conditions [5]; The hybrids of Sphagneticola trilobata $\times$ calendulacea were intermediate in invasive potential compared to their parents in shade and open environments [6]. Besides, the hybrids own a potential of transgressive segregation to produce new hybrid traits that allowing the individuals own a 
particular ecological niche rather than intermediate [7]. Thus, studies on the physiological and biochemical patterns of plants, especially the hybrids lead to new insight into adaption and evolution of plant species.

Photosynthesis, which refers to assimilating of the atmospheric $\mathrm{CO}_{2}$, is complex biophysical and chemical process [8]. Leaves are specialized for photosynthesis where the $\mathrm{CO}_{2}$ can be trapped into the spongy tissue [8]. Furthermore, chloroplasts, which chiefly spread in leaves, are the sole organelles responsible for the process of photosynthesis, and influencing photosynthesis with different quantity and content in angiosperm [9]. The effective photosynthesis is closely related to the great plant growth and increased carbohydrate accumulation [10]. Additionally, the vegetative growth superiority usually results from the strongest photosynthetic performances [11].

Plant growth superiority is not only closely related to photosynthetic capacity, but also limited by nutrient stoichiometry (e.g. nitrogen $(\mathrm{N})$ and phosphorus $(\mathrm{P})$ ) in living cells [12-15]. In vascular plants, leaf $\mathrm{N}$ is closely related to plant photosynthesis capacity, while $\mathrm{P}$ predominately drives the generation and maintenance of proteins [16]. Moreover, leaf $\mathrm{P}$ content may play more important roles than $\mathrm{N}$ element. Based on growth rate hypotheses (GRH), plant growth rate was not only chiefly limited by $\mathrm{N}$ and $\mathrm{P}$ contents, but also the ratios $[12-14,16]$ For example, $N: P$ ratio $\$ 14$ indicates $N$ limitation, while a ratio $₫ 16$ suggests $P$ limitation $[13,17]$.

Buddleja (Scrophulariaceae) species usually presented phenotype diversification because of polyploidy or hybridization [18-20]. Polyploidy has always been recognized as a strongest force in phenotype diversification, and it may be one of the most important mechanisms in plant evolution and rapid speciation, especially in Buddleja species $[19,21]$. In addition, we noted that inter-specific hybridizations between Buddleja species were common and can easily take place [18-20]. For example, Liao [20] identified the natural hybridization and asymmetric introgression between B. crispa and B. officinalis in Yunnan province. Besides, it is one of the newest identified natural hybridizations in Buddleja [20]. Thus, it was an interesting model to study the inter-specific hybridization effects and adaptive mechanisms.

In the field, B. crispa and B. officinalis and their F1 hybrids showed different morphological traits, especially the leaf morphology. For example, $B$. crispa usually grow with cordate stipules, petiole often winged and leaves covered white densely tomentose; The leaves of $B$. officinalis usually cover yellow tomentose on lower leaf epidermis; While, F1 hybrids dominated cover white tomentose on the epidermis of young leaves and the lower leaf epidermis of mature leaves. Besides, F1 hybrids showed different leaf shapes compared to the parental species. What's more interesting is that they grow at divergent habits, though they share sympatric distribution in the field. In the natural hybrid zones (e.g., Xishan mountain, Yimen, Cangshan mountain; personal observation), the parental species B. crispa and B. officinalis prefer dry cliffs with more rocks and open lands, respectively. However, F1 hybrids prefer scrubland or understory. 
To better understand the environmental acclimatization of F1 hybrids, we examined the growth and photochemical attributes compared to their parents in a homogenous garden. Asian Buddleja taxa were secondarily originated from Sino-Himalayan region, and over $85 \%$ of the Asian Buddleja species were distributed in this area $[18,21,22]$. Until recently, researchers have always been interested in pharmaceutical value, pollination ecology and genetic diversity of Buddleja species, but it is limited to plant physioecological properties and acclimatization [23]. In this work, our objective was to provide a starting point toward a better understanding of how Buddleja hybrids adapt to the ecological environment at physiological and biochemical levels. Specifically, we addressed the following questions: (1) What are the differences between F1 hybrids and their parents in plant growth and photosynthetic activities; (2) Why F1 hybrids grow in heterogeneous habits with their parents in the field? (3) What are the physioecological acclimatization properties of F1 hybrids?

\section{Results}

\section{Plant growth}

All Buddleja individuals performed well at the experimental base of Honghe University after transplanted for six months. They produced many strong new branches, and plant heights have up to $1.0 \mathrm{~m}$ height. An apparent morphological difference between species was noticed.

The growth traits, including leaf area (LA), specific leaf area (SLA), leaf mass per area (LMA) and leaf dry matter content (LDMC) were evaluated. F1 hybrids were intermediate to their parental species in all measured growth features (Fig. 1). All the three Buddleja species presented great LA with no significant differences $(P \otimes 0.05)$, and it ranged from $93.21 \pm 4.38$ to $109.15 \pm 8.97 \mathrm{~cm}^{2}$ (Fig. 1A). B. crispa has the largest LA, but the minimum for another parental species $B$. officinalis (Fig. 1A). The SLA showed the same tendency as in LA, ranged from $14.46 \pm 1.41$ to $19.89 \pm 0.8 \mathrm{~cm}^{-2} \cdot \mathrm{g}^{-1}$ (Fig. 1B). While, the SLA in $B$. crispa showed significant differences (Pख0.05) compared to the other species.

LDMA and LMA showed the adverse tendency, and B. officinalis has the maximum (Fig. 1C, D). But, there was no significant difference between $B$. officinalis and $\mathrm{F} 1$ hybrids $(P \otimes 0.05)$. B. crispa showed the

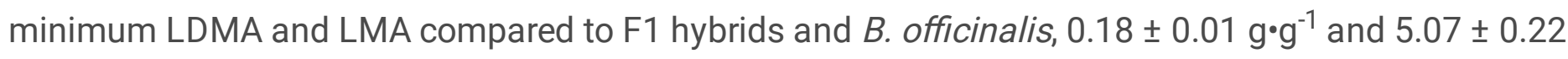
$\mathrm{mg} \cdot \mathrm{cm}^{-2}$, respectively (Fig. 1C, D). And there were significant differences $(P \otimes 0.05)$ between the two parental species.

\section{Chlorophyll contents}

All the three Buddleja species produced great chlorophyll pigment (Table 1). F1 hybrids produced the largest chlorophyll a and the total chlorophyll content, $8.02 \pm 0.26$ and $10.41 \pm 0.56 \mathrm{mg}^{\circ} \mathrm{g}^{-1}$, respectively (Table 1). B. officinalis produced the greatest chlorophyll b $\left(3.33 \pm 0.49 \mathrm{mg}^{-1} \mathrm{~g}^{-1}\right)$, but with the minimum chlorophyll a and the total chlorophyll (Table 1). 
Additionally, F1 hybrids showed the greatest chlorophyll a/b ratio, $3.73 \pm 0.09$ (Table 1). B. crispa was secondary (3.61 \pm 0.11$)$, but showing no significant difference $(P \otimes 0.05)$ with $\mathrm{F} 1$ hybrids (Table 1$). B$. officinalis showed the minimum chlorophyll $\mathrm{a} / \mathrm{b}$ ratio $0.93 \pm 0.24$. And it showed significant difference $(P]$ 0.05) compared to $\mathrm{F} 1$ hybrids and B. crispa.

\section{Leaf C, N, P stoichiometry}

The leaf carbon (C), nitrogen $(\mathrm{N})$ and phosphorus $(\mathrm{P})$ stoichiometric characteristics among the three Buddleja species were measured (Fig. 2). All the three Buddleja species produced great $\mathrm{C}$ in their leaves, ranging from $606.0 \pm 3.46$ to $706.0 \pm 2.0 \mathrm{mg}^{-1} \mathrm{~g}^{-1}$ (Fig. 2A). B. crispa produced the maximum foliar $\mathrm{C}$ content, and $B$. officinalis secondary. Although F1 hybrids stored the lowest foliar $\mathrm{C}$, it collected great $\mathrm{N}$ and $P$ nutrient ( $20.47 \pm 0.00$ and $1.58 \pm 0.00$, respectively), especially the $N$ (Fig. $2 B, C$ ). B. officinalis gathered the minimum $\mathrm{N}\left(20.47 \pm 0.001 \mathrm{mg} \cdot \mathrm{g}^{-1}\right)$ and $\mathrm{P}\left(0.99 \pm 0.005 \mathrm{mg}^{\circ} \mathrm{g}^{-1}\right)$ elements compared with $B$. crispa and $\mathrm{F} 1$ hybrids. And there was significant difference $(P \otimes 0.05)$ in foliar $\mathrm{C}, \mathrm{N}$ and $\mathrm{P}$ content between the three Buddleja species.

The three Buddleja species also showed the great C:P and N:P ratios (Fig. 2D, E). B. officinalis showed the greatest $\mathrm{C}: \mathrm{P}(31.25 \pm 0.09)$ and $\mathrm{N}: \mathrm{P}(20.82 \pm 0.23)$ ratios. $\mathrm{F} 1$ hybrids showed an intermediate N:P ratio, but the lowest C:P ratio. And it was significantly different in N:P and C:P ratios compared with their parental species $(P \otimes 0.05)$.

In addition, the photosynthetic nitrogen use efficiency (PNUE) in these species were also evaluated (Fig. 2F). $\mathrm{F} 1$ hybrids showed the lowest PNUE $0.68 \pm 0.04 \mu \mathrm{mol} \mathrm{CO}_{2} \cdot \mathrm{mol}^{-1} \cdot \mathrm{s}$. It was significantly lower than that in their parental species $(P \otimes 0.05)$. The parental species $B$. crispa showed the greatest PNUE $(1.34 \pm$ $\left.0.05 \mu \mathrm{mol} \mathrm{CO}{ }_{2} \cdot \mathrm{mol}^{-1} \cdot \mathrm{s}^{-1}\right)$, and $B$. officinalis was secondary.

\section{Gas-exchange in diurnal variation}

1. crispa and $B$. officinalis showed the same tendency in net photosynthetic rate $(\mathrm{Pn})$, stomatal conductance (Gs), transpiration rate (E), vapor pressure deficit of leaf (VpdL), water-use efficiency (WUE) and light-use efficiency (LUE) in respond to diurnal photon flux density (PPFD) variation (Fig. 3). But, $\mathrm{F} 1$ hybrids showed different patterns compared to their parents. Both B. crispa and $B$. officinalis present clear midday depression of photosynthesis between12:00 and14:00 (Fig. 3A). The E, Gs and VpdL continually increased during these times (Fig. 3B, C, D).

However, F1 hybrids did not markedly reduce its photosynthesis during the midday time, and keeping high carbon assimilation rate during the day time (Fig. 3A). The maximum Pn can up to $10.48 \pm 0.50 \mathrm{mmol}$ $\mathrm{CO}_{2} \cdot \mathrm{mmol}^{-1}$ photo. To the contrary, it strikingly reduced their $\mathrm{E}$ and $\mathrm{Gs}$ levels after expose to gradually 
increased PPFD (Fig. 3B, C). And it keeps E and Gs at a low level after 12:00. But, it markedly increased their VpdL level during the midday time (Fig. 3D). The maximum VpdL can up to $4.18 \pm 0.55 \mathrm{kPa}$.

The WUE and LUE among these species were also evaluated (Fig. 3). F1 hybrids keep raising the WUE level during the day time (Fig. 3E). The maximum WUE can up to $21.52 \pm 2.20 \mu \mathrm{mol} \cdot \mathrm{mmol}^{-1}$. But, the parental species $B$. crispa and $B$. officinalis gradually decreased their WUE level with diurnal PPFD variation, and it was markedly lower than that in F1 hybrids. All the three Buddleja species showed the same tendency in LUE (Fig. 3F). But, F1 hybrids rapidly increased it after 16:00 at low PPFD.

\section{Photosynthetic response to light}

Photosynthetically active radiation (PAR)-Pn response curves revealed the photosynthetic properties of each species in respond to changing light conditions, and it was listed in Table 2. F1 hybrids showed the lowest apparent quantum yield (AQY), light-saturated net photosynthetic rate (Pmax) and rate of respiration (Rd) than their parents. And it was only $0.06 \pm 0.001 \mathrm{mmol} \mathrm{CO}_{2} \cdot \mathrm{mmol}^{-1}$ photo, $9.19 \pm$ $0.41 \mu \mathrm{mol} \mathrm{CO} \mathrm{Cm}_{2} \cdot \mathrm{m}^{-2} \cdot \mathrm{s}^{-1}$ and $1.14 \pm 0.05 \mathrm{mmol} \mathrm{CO}{ }_{2} \cdot \mathrm{m}^{-2} \cdot \mathrm{s}^{-1}$, respectively (Table 2 ).

Although they showed different AQY, Pmax and Rd, the light compensation point (LCP) and light saturation point (LSP) were similar, with no significant differences ( $P \otimes 0.05$; Table 2). Moreover, F1 hybrids have the lowest LCP $1.14 \pm 0.05 \mathrm{mmol} \mathrm{CO}_{2} \cdot \mathrm{m}^{-2} \cdot \mathrm{s}^{-1}$ (Table 2).

\section{Chlorophyll a fluorescence}

Chlorophyll a fluorescence traits after dark and light-adapted of the three Buddleja species were exhibited in Fig 4. All the three Buddleja species showed great maximum photochemical efficiency of PSII (Fv/Fm), ranging from $0.83 \pm 0.004$ to $0.85 \pm 0.004$ (Fig. 4A). To the contrary, they have high photochemical efficiency of PSII in the light ( $\left.\mathrm{Fv}^{\prime} / \mathrm{Fm}^{\prime}\right)$ and low non-photochemical quenching (NPQ), ranging from $0.5 \pm$ 0.01 to $0.55 \pm 0.02$ and $1.22 \pm 0.15-1.97 \pm 0.08$, respectively (Fig. 4B, D). Furthermore, they showed great photochemical activity with high photochemical quenching (Qp), effective quantum yield (DPSII) and electron transport rate (ETR).

F1 hybrids have the highest Qp, NPQ, ФPSII and ETR than their parental species, though there was no significant difference ( $P \otimes 0.05)$ between $\mathrm{F} 1$ hybrids and $B$. officinalis (Fig. $4 \mathrm{C}, \mathrm{D}, \mathrm{E}, \mathrm{F})$. B. crispa showed the lowest Qp, NPQ, ФPSIl and ETR compared to other two species with significant difference (P冈0.05).

\section{Inter-specific variations in the three Buddleja species}


To evaluate inter-specific differences in detail, plant growth, gas-exchange and chlorophyll a fluorescence traits at individual levels were examined in the three Buddleja species (Fig. 5). According to the results of principal component analysis (PCA), PCA 1 and 2 explained $46.76 \%$ and $18.94 \%$ of the total variations, respectively. Moreover, gas-exchange traits, such as $\mathrm{E}, \mathrm{Gs}$, contributed greatly to the parental species $B$. crispa and B. officinalis. However, chlorophyll fluorescence, such as Qp, ФPSII and ETR and WUE contributed greatly to $\mathrm{F} 1$ hybrids.

\section{Growth potential of the three Buddleja species}

To evaluate environmental acclimatization of these Buddleja species, the membership function values were calculated based on all investigated traits (Table 3). B. crispa showed the greatest $u X j, \otimes W \rrbracket \rrbracket$ and $\mathrm{D}$ values, $0.53 \pm 0.02,10.39 \pm 2.34$ and 179.23 , respectively. While, the other parent $B$. officinalis showed the lowest. F1 hybrids are intermediate to their parental species, and have great D value 83.14 (Table 3).

\section{Discussion}

Hybridization can immediately have the phenotypic consequence and local adaption through take advantage of hybrid vigor [7]. F1 hybrid in this study was a new identified natural hybridization between B. crispa and B. officinalis by Liao [20]. They are not only having divergent morphology and inheritance, but also the living habitats [20]. In the present work, the performances and physioecological properties of three Buddleja species under homogenous garden cultivation were evaluated. To maximize light capturing in low light intensity, plant species usually increased their SLA, and decreased their biomass through spread out leaf size and thinner it [24]. In this work, all three Buddleja species performed well with large LAs (Fig. 1). The parental species B. crispa have the greatest SLA and the minimum LDMC. And F1 hybrids are intermediate to their parents in SLA and LDMC. Smart [25] believed that LDMC is better at predicting plant growth and performance than SLA, though plants may adjust a suite of morphological and physiological traits. Thus, our results suggested that F1 hybrids were an intermediate to their parents in plant growth potential in the homogenous garden. In general, inter-specific hybridization may result in chlorophyll deficiency [5], and the deficiency of chlorophyll b was adverse to chlorophyll biosynthesis [26, 27]. In this study, F1 hybrids synthesized the greatest total chlorophyll pigment and chlorophyll $b$ than their parents (Table 1). Besides, they showed the greatest chlorophyll a/b ratio, which was an indicator of the balance between light harvesting and photosynthesis [28]. Meanwhile, it is positively correlated to the size of photosynthetic unit of the individual photosystem [28]. Thus, these results implied that F1 hybrid in Buddleja was not only an intermediate compared to their parental species, but also it may have more powerful photosynthetic capacity and environmental acclimatization. Stoichiometric characteristics, especially the foliar $\mathrm{N}$ content are either closely associated with plant growth and productivity, or play important roles in plant functions, such as driving photosynthesis $[13,16,29]$. PNUE has always been used in determining the efficiency of plant species use $\mathrm{N}$ to achieve growth [30, 31]. However, F1 hybrids showed the minimum PNUE, though they collected a larger amount of $\mathrm{N}$ in their leaves than their parents 
(Fig. 2F). Onoda [32] found that decreased photosynthetic N-use efficiency in plant species may be resulted from allocation of $\mathrm{N}$ to cell walls. Moreover, the great LMA, which was an index of structural (cellwall) biomass [33], in F1 hybrids further support it (Fig. 1D). The trade-off between $\mathrm{N}$ allocation to cell walls and to Rubisco usually correlated with different leaf life spans [41]. What's more, F1 hybrids showed great $\mathrm{P}$ content and relative lower N:P ratio (Fig. 2), which is closely correlated with plant growth based on the growth rate hypothesis $(\mathrm{GRH})[12,34,35]$. So, our results suggested that $\mathrm{F} 1$ hybrids may keep high growth rate and great biomass production through extend leaf life spans. In addition, the results of membership function comprehensive assessment also supported that $\mathrm{F} 1$ hybrids performed well as their parents (Table 3). The hybrid vigor in F1 hybrids was consistent with the results of Kölreuter [36] that early-generation hybrids always show intermediate phenotype compared to their parents. Moreover, F1 hybrids showed greatly local adaption through species-specific ways, such as divergent photosyntheitc characteristics (e.g., Gs, E, WUE, LUE) and chlorophyll fluorescence attributes (e.g., Qp, ФPSII, ETR). These divergent photochemical patterns may facilitate F1 hybrids to respond to different habitats, and to impove growth performance in the field. Divergent gas-exchange patterns of F1 hybrids In plants, different photosynthetic attributes may affect species distribution and habitat difference [37, 38]. In the present work, F1 hybrids showed the parallel LCP and LSP levels compared to their parents with no significant differences (P凶0.05; Table 2). However, they showed low AQY, Pmax and Rd compared to their parents, especially the AQY (Table 2). And it was significantly lower than their parents (P凶0.05). The AQY, Pmax and Rd are important features not only in determining the shape of the light response curve, but also describing species-specific photosynthetic activity [39]. So, the reduced AQY in F1 hybrids implied that they have lower utilization efficiency of low-light density than their parents. In the fields, plants are continuously suffered from complex environmental conditions, which may affect leaf photosynthesis and often occur simultaneously. Leaf acclimation to divergent habitats occurs mainly through modification of leaf photosynthesis, such as carbon assimilation rates, water use efficiency and light use efficiency [40]. After exposure to increasing light intensifies, Gs and $\mathrm{E}$ in the parental species were varied positively with the PPFD (Fig. 3). However, F1 hybrids showed different gas-exchange patterns compared to their parents. They markedly reduced Gs and E during 8:00 - 12:00, and kept it at a low level during the whole afternoon (Fig. 3). These results suggested that F1 hybrids respond sensitively and negatively to high light intensity. F1 hybrids showed a weak tolerance to strong light intensity, and high PPFD may induce the closure of stomata, but not their parents. Although the limited Gs reduced the evaporation of water from leaves, F1 hybrids markedly enhanced leaf WUE (Fig. 3). Meanwhile, they kept high carbon assimilation rates during the day with markedly increased VpdL. The diverse gas-exchange patterns in $\mathrm{F} 1$ hybrids provided species-specific environmental acclimatization, especially the high-light intensity. Furthermore, this was consistent with the results that F1 hybrids synthesized the greatest chlorophyll content, which was positively related to plant growth and biomass production than their parental species (Table 1). Acclimatization potential of F1 hybrids Chlorophyll a fluorescence provided an insight into the capacity of a plant to tolerate environmental stresses and into the extent to which those stresses have damaged the photosynthetic apparatus [41]. The Fv/Fm ratio has always been a sensitive indicator for evaluating abiotic stress on PSII [42, 44], with optimal values of around 0.83 for most plant species [45]. In this homogenous garden work, all three Buddleja species showed great maximum 
quantum yield with high Fv/Fm ratios ranged from $0.83 \pm 0.0035$ to $0.85 \pm 0.004$ (Fig. 4). However, F1 hybrids showed higher NPQ than their parents, which implied the higher extent of heat dissipation for excessive excitation energy [46]. This indicated that F1 hybrids showed weak tolerance to strong light compared to their parents. In addition, all Buddleja species in this study showed low level of NPQ and high Fv'/Fm' (Fig. 4B, D). Thus, our results suggested that all Buddleja species in this study were not suffered from photoinhibition or other environmental stresses. Chlorophyll a fluorescence represents the leaf photochemical efficiency and growth acclimatization of plants to species-specific environments [46]. It competes for excitation energy with photochemistry process, especially photosynthesis [41]. In this study, F1 hybrids showed the greatest Qp than their parents, which indicated the high electron transport activities in PSII [47], especially the B. crispa. Simultaneously, the ETR and ФPSII, which account for plant health and performance $[44,46]$ presented a similar behavior to Qp in F1 hybrids (Fig. 4). This implied that the rise of DPSII in F1 hybrids is mainly dependent on the increase of proportion of PSII reaction center capable of photochemistry [47]. It was consistent with Miyata [48] that plants showed better light energy utilization on photochemistry usually with high levels of Fv'/Fm', Qp, ETR and ФPSII. Associated with the growth performance of F1 hybrids in the homogenous garden, our results suggested that F1 hybrids have great photochemical activities and growth acclimatization compared to their parents.

\section{Conclusion}

Our results demonstrated that F1 hybrid was an intermediate and performed well in the homogenous garden compared to their parents. Although F1 hybrids have lower utilization efficiency of low-light density than their parental species, they showed the parallel LCP and LSP. During the diurnal variation of photosynthesis, they showed divergent gas-exchange patterns compared to their parents after exposure to high PPFD. In addition, F1 hybrids not only showed great Fv/Fm ratio and low NPQ, but also have higher Qp, ФPSII and ETR levels than their parents. Furthermore, F1 hybrids showed weak tolerance to strong light compared to their parents. Associated with the growth performance of F1 hybrids in the homogenous garden, our results suggested that the divergent gas-exchange and chlorophyll fluorescence patterns may facilitate F1 hybrids to respond to different habitats, and to impove growth performance in the field.

\section{Methods}

\section{Materials}

In the field, three natural hybrid zones of $B$. crispa and B. officinalis, including Xishan mountain

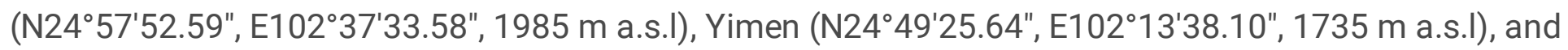

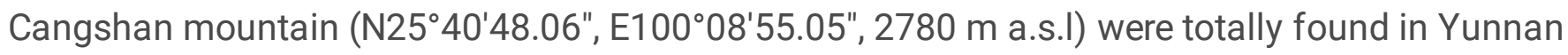
province, China. At all these three natural ranges, $B$. crispa grew with small dry leaves because of drought and hydropenia (Fig. 6A). 
In this study, the parental species $B$. crispa and $B$. officinalis, and $\mathrm{F} 1$ hybrids were introduced and transplanted into the experimental base of Honghe University during 25 - 30 August, 2018 (Fig. 6). Five individuals for each taxon were introduced from Xishan mountain. The cultivation environment is relatively moist and cover-overheaded, which is closer to the natural habitat of F1 hybrids. After cultivated for six months, the plant growth and photosynthetic characteristics were evaluated. This study was carried out during 21 February - 28 March, 2019. The mature leaves from annual shoots were used. We have got a permission to collect and conserve F1 hybrids and their parental species in the experimental base of Honghe University, and each species have been identified by Dr. Rongli Liao. Vouchers specimens of each species were deposited at the Herbarium of College of Life Science and Technology, Honghe University.

\section{Leaf trait measurement}

All selected mature leaves were floated in water at dark for $₫ 12$ hours. The secondary day, each leaf was dried and weighted for leaf saturated fresh weight following Shah [49]. Six replicates for each taxon were performed. LA of fresh leaves was also scanned, and digitized by using Image $\mathrm{J}$.

Then, all the leaves were marked and oven-dried at $105^{\circ} \mathrm{C}$ for $5 \mathrm{~min}$, and dried to constant weight at $70^{\circ} \mathrm{C}$ for three days following [49]. The leaf dry weight of each leaf was recorded. SLA, LMA and LDMC were further calculated following [25].

\section{Chlorophyll determination}

Chlorophyll content was extracted by using N, N-dimethylformamide following Niu [50]. The fitting leaf area $\left(0.5 \mathrm{~cm}^{2}\right.$, fresh weight) material of each species was punched from fresh leaves (avoiding major leaf veins where possible) through a circular leaf discs puncher $(\varnothing=5 \mathrm{~mm})$. Six $0.5 \mathrm{~cm}^{2}$ leaf disks from six different leaves of each taxon was used, and immerged in $\mathrm{N}, \mathrm{N}$-dimethylformamide for $\otimes 12 \mathrm{~h}$ at dark. Each taxon does three repetitions. Then the supernatant was collected by centrifugation at $1000 \mathrm{r} / \mathrm{min}$ for $10 \mathrm{~min}$, and the absorption values were record by Ultraviolet-visible Spectrophotometer (UV 5100B, Shanghai Metash Instrument Co., Ltd., Shanghai, China) at 664.5 and $647 \mathrm{~nm}$, respectively. Three repetitions for each taxon were performed. Then the concentration of chlorophyll was expressed as follows [50-51]:

Chlorophyll a $=12.70 \mathrm{~A}_{664.5}-2.79 \mathrm{~A}_{647}$;

Chlorophyll $b=20.70 \mathrm{~A}_{647}-4.62 \mathrm{~A}_{664.5}$

Total Chlorophyll $=17.90 \mathrm{~A}_{647}+8.08 \mathrm{~A}_{664.5}$ 


\section{Leaf $\mathrm{C}, \mathrm{N}$, and P stoichiometry}

Five dried leaves in each taxon were selected and ground to fine power to pass through a $0.15 \mathrm{~mm}$ sieve for $\mathrm{C}, \mathrm{N}$ and $\mathrm{P}$ analysis. Three repetitions for each taxon were performed. The organic $\mathrm{C}$ concentration of plant samples was analyzed by the Walkley-Black modified acid-dichromate $\mathrm{FeSO}_{4}$ titration method [52]. The total $\mathrm{N}$ content of plant samples was determined after micro-Kjeldhl digestion using a flow injection autoanalyzer. The total $\mathrm{P}$ content was analyzed colorimetrically by the ammonium molybdate method $[52,53]$. Plant $\mathrm{C}, \mathrm{N}$, and $\mathrm{P}$ contents were expressed as $\mathrm{g} \mathrm{kg}^{-1}$ on a dry weight basis. Stoichiometric ratios in leaves were also calculated on a mass basis.

Additionally, the PNUE was further evaluated according to Poorter and Evans [30]. It was calculated as follows:

PNUE $=\operatorname{Pmax} /(1 / 14$ Nmass $\times$ LMA $)$

where Pmax is the maximum photosynthesis rate of different plant species, Nmass is the leaf nitrogen content per unit mass, and LMA is leaf dry mass per unit area.

\section{Leaf gas exchanges}

Diurnal variations of photosynthesis of mature leaves were measured by using Li-6400XT portable photosynthesis system with a standard $6 \mathrm{~cm}^{2}$ leaf chamber (Li-Cor Inc., USA). And it was determined under natural light intensity during 11 March and 29 March, 2019. The 7-8th mature leaves below the plant apex within a new (less than one-year old) branch were used.

At a sunny day, photosynthesis parameters and environmental data were recorded every two hours between 8:00 and 18:00 h [11]. Pn, Gs, E and VpdL were evaluated. WUE (Pn/ E ratio) and LUE (Pn/ PPFD ratio) were also calculated and assessed. Five different leaves were used for each taxon, and three repetitions were logged for each leaf.

PAR-Pn response curves were evaluated between $8: 30$ and 11:30 by using Li-6400XT portable photosynthesis infrared gas analyzer (IRGA) system (Li-Cor Inc., USA). The environmental $\mathrm{CO}_{2}$ concentration was used and $6 \mathrm{~cm}^{2}$ cuvette was fitted with a red-blue light source (6400-02B). 13 different PPFD gradient, including 2000, 1800, 1500, 1200, 800, 500, 200, 100, 80, 50, 20, 10, $0 \mu \mathrm{mol} \cdot \mathrm{m}^{-2} \cdot \mathrm{s}^{-1}$ were designed. The 7-8th mature leaves from top of the twigs were used, and five repetitions were performed for each taxon.

The chlorophyll fluorescence parameters were recorded by using Li-6400XT portable photosynthesis system with a fluorescent leaf chamber (Li-Cor Inc., USA). After dark-adapted for 30 min, Fo and Fm were 
recorded. The following day (9:00 - 11:00), the chlorophyll a fluorescence traits of the same leaf were further evaluated. A saturating light pulse $\left(1200 \mu \mathrm{mol}\right.$ quanta $\left.\mathrm{m}^{2} \mathrm{~s}^{-1}, 1 \mathrm{~s}\right)$ was applied for closing all reaction centers. And the Fo', Fm' and Fs were recorded.

Then, Fv/Fm (Fv/Fm = (Fm - Fo)/ Fm), Fv'/Fm', ETR, ФPSII (ФPSII = (Fm'- Fs)/Fm', Qp (Qp = 1-(Fs$\left.\left.\mathrm{Fo}^{\prime}\right) /\left(\mathrm{Fm}^{\prime}-\mathrm{Fo} \mathrm{o}^{\prime}\right)\right)$ and NPQ $\left(\mathrm{NPQ}=\left(\mathrm{Fm}-\mathrm{Fm}^{\prime}\right) / \mathrm{Fm}^{\prime}\right)$ were further calculated [54-56].

\section{Data analysis}

The fitting parameters of light response curve, including Pmax, AQY (slope of the linear portion of the light response curve), LCP, LSP and Rd in the light were fitted with a modified model of non-rectanngular hyperbola according to Ye [57].

The contribution of each growth and photosynthetic parameters among species was estimated by using PCA in PAST (2.0 version). A variance-covariance matrix of their parameters was used. In the diurnal variations of photosynthesis, the mean values were used to evaluate the performance of each parameter. Prior to PCA, all the data were standardized by using log-transforms base on 10 logarithm. To assess the ecological adaptation of each species, the membership function value of each Buddleja species was also calculated by using the modified equations according to 
Liu [58]:

$$
\begin{aligned}
& u\left(X_{j}\right)=\frac{\left(X_{j}-X_{\min }\right)}{\left(X_{\max }-X_{\min }\right)}, \mathrm{j}=\underline{1,2, \ldots,}, \mathrm{n} \\
& W_{j}=\left|P_{j}\right| / \sum_{j=1}^{n}\left|P_{j}\right|, \mathrm{j}=\underline{\underline{1,2, \ldots,}}, \mathrm{n} \\
& D=\sum_{j=1}^{n}\left[u\left(X_{j}\right) \times W_{j}\right], \mathrm{j}=\underline{1,2, \ldots,}, \mathrm{n}
\end{aligned}
$$

where $u\left(X_{j}\right)$ is the membership function value for adaptability of the trait $(\mathrm{j})$; $X_{j}, X_{\min }$ and $X_{\max }$ are the mean, minimum and maximum values of the trait (j), respectively; $P_{j}$ is the contribution rate of the trait (j) based on principal component analysis; $W_{j}$ is rate of the contribution of the trait (j) in all studied traits. D is the comprehensive membership function value for adaptability of species.

One-way analysis of variance (ANOVA) was performed to reveal the difference between the hybrids and parental species. The software PAST (2.0 version) was used for the statistical analysis. Mean separation was done using the Duncan Multiple Range Test of $P \otimes 0.05$. SigmaPlot software (Version 14.0, Systat Software, San Jose, CA) was used for graphical works, and then adjusted and assembled with Adobe Illustrator CS4 (Adobe Systems, San Jose, CA).

\section{Declarations}

\section{Abbreviations}

N: Nitrogen; P: Phosphorus; GRH: Growth rate hypotheses; LA: Leaf area; LDMC: Leaf dry matter content; LMA: Leaf mass per area; SLA: Specific leaf area; PNUE: Photosynthetic nitrogen use efficiency; Pn: Net photosynthetic rate $(\mathrm{Pn})$; Gs: Stomatal conductance; E: Transpiration rate; VpdL: Vapor pressure deficit of leaf; LUE: Light-use efficiency; WUE: Water-use efficiency; IRGA: Infrared gas analyzer; PPFD: Photon flux density; Fo: Minumum fluorescence yield in dark-adapted state; Fm: Maximum fluorescence yield in darkadapted state; Fo': Minumun fluorescence yield in light-adapted state; Fm': Maximum fluorescence yield in light-adapted state; Fs: steady-state fluorescence yield; Pmax: Light-saturated net photosynthetic rate; PAR: Photosynthetically active radiation; AQY: Apparent quantum yield; Rd: Rate of respiration; LCP: Light 
compensation point; LSP: Light saturation point; Fv/Fm: maximum photochemical efficiency of PSIl; Fv'/Fm': Photochemical efficiency of PSIl in the light; ETR: Electron transport rate; Qp: Photochemical quenching; NPQ: Non-photochemical quenching; ФPSII: Effective quantum yield; PCA: Principal component analysis.

\section{Acknowledgements}

We thanks Fuqiong Bai and Yanmei Luo for the helps in the field work of photosynthetic and chlorophyll fluorescence attributes measurement at Honghe University.

\section{Authors' contributions}

Conceived and designed the experiments: GWC and CYQ; Performed the experiments: GWC, WJ and YH; Analyzed the data: GWC and CYQ; Wrote the paper: GWC; Revised the manuscript: CYQ and WJ. All authors have read and approved the manuscript.

\section{Funding}

This work is supported by the Natural Science Foundation of China (Grant No. NSFC-31660111) and Honghe University (Grant No. XJ14Z01, XJ15B17 and XJ16B05). The funding bodies were not involved in the design of the study, collection, analysis and interpretation of data, and in writing the manuscript.

\section{Availability of data and materials}

The datasets used and/or analyzed during the current study are available from the corresponding author on reasonable request.

\section{Ethics approval and consent to participate}

Not applicable.

\section{Consent for publication}

Not applicable. 


\section{Competing interests}

The authors declare that they have no competing interests.

\section{Author details}

${ }^{1}$ College of Life Science and Technology, Honghe University, Mengzi, Yunnan 661199, China. ${ }^{2}$ College of Teacher Education, Honghe University, Mengzi Yunnan 661199, China

\section{References}

1. Martin NH, Bouck AC, Arnold ML. Detecting adaptive trait introgression between Iris fulva and I. brevicaulis in highly selective field conditions. Genetics. 2006;172(4):2481-2489.

2. Ma YP, Zhang CQ, Zhang JL, Yang JB. Natural hybridization between Rhododendron delavayi and $R$. cyanocarpum (Ericaceae), from morphological, molecular and reproductive evidence. J Integr Plant Biol. 2010;52(9):844-851.

3. Ma YP, Tian XL, Zhang JL, Wu ZK, Sun WB. Evidence for natural hybridization between Primula beesiana and $P$. bulleyana, two heterostylous primroses in NW Yunnan, China. China. J Syst Evol. 2014;52(4):500-507.

4. Moriuchi KS, Winn AA. Relationships among growth, development and plastic response to environment quality in a perennial plant. New Phytol. 2005;166(1):149-158.

5. Yu X, Hyldgaard B, Rosenqvist E, Ottosen CO, Chen J. Interspecific hybridization in Cucumis leads to the divergence of phenotypes in response to low light and extended photoperiods. Front Plant Sci. 2015;6:802.

6. Li T, Huang LX, Yi L, Hong L, Shen H, Ye WH, Wang ZM. Comparative analysis of growth and physiological traits between the natural hybrid Sphagneticola trilobata $\times$ calendulacea and its parental species. Nordic J Bot. 2016;34(2):219-227.

7. Goulet BE, Roda F, Hopkins R. Hybridization in plants: old ideas, new techniques. Plant Physiology. 2017;173(1): 65-78.

8. Douthe C, Gago J, Ribas-Carbó M, Núñez R, Pedrol N, Flexas J. Measuring Photosynthesis and Respiration with Infrared Gas Analysers//Advances in Plant Ecophysiology Techniques. Springer, Cham; 2018:51-75.

9. Mathur S, Jain L, Jajoo A. Photosynthetic efficiency in sun and shade plants.

Photosynthetica.2018;56(1):354-365.

10. Liao T, Cheng S, Zhu X, Min Y, Kang X. Effects of triploid status on growth, photosynthesis, and leaf area in Populus. Trees. 2016;30(4):1137-1147. 
11. Cao Q, Zhang X, Gao X, Wang L, Jia G. Effects of ploidy level on the cellular, photochemical and photosynthetic characteristics in Lilium FO hybrids. Plant Physiol Bioch. 2018;133:50-56.

12. Elser JJ, Acharya K, Kyle M, Cotner j, Makino W, Watts T, Hobbie S, Fagan W, Schade J, Hood J, Sterner RW. Growth rate-stoichiometry couplings in diverse biota. Ecol Lett. 2003;6(10):936-943.

13. Güsewell S. N: P ratios in terrestrial plants: variation and functional significance. New Phytol. 2004;164(2):243-266.

14. Niklas KJ, Owens T, Reich PB, Cobb ED. Nitrogen/phosphorus leaf stoichiometry and the scaling of plant growth. Ecol Lett. 2005;8(6):636-642.

15. Sardans J, Peñuelas J. The role of plants in the effects of global change on nutrient availability and stoichiometry in the plant-soil system. Plant Physiol. 2012;60(4):1741-1761.

16. Tian D, Yan Z, Niklas KJ, Han W, Kattge J, Reich PB, Luo YK, Chen YH, Tang ZY, Hu HF, Wright IJ, Schmid B, Fang JY. Global leaf nitrogen and phosphorus stoichiometry and their scaling exponent. Natl Sci Rev. 2017;5(5):728-739.

17. Koerselman W, Meuleman AFM. The vegetation N: $P$ ratio: a new tool to detect the nature of nutrient limitation. J Appl Ecol. 1996;33(6):1441-1450.

18. Norman E M, Espinar L A. Buddlejaceae. Organization for Flora Neotropica, 2000;81:1-225.

19. Chen G, Sun WB, Sun H. Ploidy variation in Buddleja L. (Buddlejaceae) in the Sino-Himalayan region and its biogeographical implications. Bot J Linn Soc. 2007;154(3):305-312.

20. Liao RL, Ma YP, Gong WC, Chen G, Sun WB, Zhou RC, Marczewski T. Natural hybridization and asymmetric introgression at the distribution margin of two Buddleja species with a large overlap. BMC Plant Biol. 2015;15(1):146.

21. Li PT, Leeuwenberg AJM. Loganiaceae. In: Wu CY, Raven PH, eds. Flora of China 15. Beijing: Science Press.1996;320-332.

22. Nie ZL, Wen J, Gu ZJ, Boufford DE, Sun H. Polyploidy in the flora of the Hengduan Mountains hotspot, southwestern China. Ann Mo Bot Gard. 2005;275-306.

23. Feng $\mathrm{YL}$, Auge $\mathrm{H}$, Ebeling SK. Invasive Buddleja davidii allocates more nitrogen to its photosynthetic machinery than five native woody species. Oecologia. 2007;153(3):501-510.

24. Liu Y, Dawson W, Prati D, Haeuser E, Feng Y, van Kleunen M. Does greater specific leaf area plasticity help plants to maintain a high performance when shaded?. Ann. Bot-London. 2016;118(7):13291336.

25. Smart SM, Glanville HC, Blanes MC, Mercado LM, Emmett BA, Jones DL, Cosby BJ, Marrs RH, Butler A, Marshall MR, Reinsch S, Herrero-Jáureguiet C, Hodgson JG. Leaf dry matter content is better at predicting above-ground net primary production than specific leaf area. Funct Ecol. 2017;31(6):13361344.

26. Shimazaki K, Doi M, Assmann SM, Kinoshita T. Light regulation of stomatal movement. Annu. Rev Plant Biol. 2007;58:219-247. 
27. Terfa MT, Solhaug KA, Gislerød HR, Olsen JE, Torre S. A high proportion of blue light increases the photosynthesis capacity and leaf formation rate of Rosa $\times$ hybrida but does not affect time to flower opening. Physiol plantarum. 2013;148(1):146-159.

28. Anderson JM, Chow WS, Goodchild DJ. Thylakoid membrane organisation in sun/shade acclimation. Funct Plant Biol. 1988;15(2):11-26.

29. Tang Z, Xu W, Zhou G, Bai YF, Li JX, Tang X, Chen D, Liu Q, Ma WH, Xiong GM, He HL, He NP, Guo YP, Guo Q, Zhu JL, Han WX, Hu HF, Fang JY, Xie ZQ. Patterns of plant carbon, nitrogen, and phosphorus concentration in relation to productivity in China's terrestrial ecosystems. P Nati A Sci. 2018;115(16):4033-4038.

30. Poorter H, Evans JR. Photosynthetic nitrogen-use efficiency of species that differ inherently in specific leaf area. Oecologia. 1998;116(1-2):26-37.

31. Garnier E, Gobin O, Poorter H. Nitrogen productivity depends on photosynthetic nitrogen use efficiency and on nitrogen allocation within the plant. Ann Bot-London. 1995;76(6):667-672.

32. Onoda Y, Hikosaka K, Hirose T. Allocation of nitrogen to cell walls decreases photosynthetic nitrogenuse efficiency. Funct Ecol. 2004;18(3):419-425.

33. Wright IJ, Cannon K. Relationships between leaf lifespan and structural defences in a low-nutrient, sclerophyll flora. Funct Ecol. 2001;15(3):351-359.

34. Lind PR, Jeyasingh PD. Genotypic differences in phosphorus use physiology in producers (Chlamydomonas reinhardtii) and consumers (Daphnia pulex) interact to alter primary and secondary production. Evol Ecol. 2015;29(4):551-563.

35. Leal MC, Seehausen O, Matthews B. The ecology and evolution of stoichiometric phenotypes. Trends Ecol Evol. 2017;32(2):108-117.

36. Kölreuter JG. Vorläufige Nachricht von einigen das Geschlecht der Pflanzen betreffenden Versuchen und Beobachtungen. Gleditsch. 1761.

37. Cavaleri MA, Oberbauer SF, Ryan MG. Foliar and ecosystem respiration in an old-growth tropical rain forest. Plant, Cell \& Environment. 2008;31(4):473-483.

38. Guan T, Zhou J, Zhang X, Gao N, Du H, Cai W, Jiang LH, Lai LM, Zheng YR. The effect of photosynthetic parameters on species acclimation in an arid mountainous region of China. Turk $\mathrm{J}$ Bot. 2018;42(4):423-439.

39. Zhang LM, Yu GR, Sun XM, Wen XF, Ren CY, Fu YL, Li QK, Li ZQ, Liu YF, Guan DX, Yan JH. Seasonal variations of ecosystem apparent quantum yield (a) and maximum photosynthesis rate (Pmax) of different forest ecosystems in China. Agr Forest Meteorol. 2006;137(3-4):176-187.

40. Delagrange S. Light-and seasonal-induced plasticity in leaf morphology, $N$ partitioning and photosynthetic capacity of two temperate deciduous species. Environ Exp Bot. 2011;70(1): 1-10.

41. Guidi L, Landi M, Penella C, Calatayud A. Application of modulated chlorophyll fluorescence and modulated chlorophyll fluorescence imaging in studying environmental stresses effect. Ann BotCoenol Plant. 2016;6:5-22. 
42. Figueroa ME, Fernández-Baco L, Luque T, Davy AJ. Chlorophyll fluorescence, stress and survival in populations of Mediterranean grassland species. J Veg Sci. 1997; 8(6):881-888.

43. Oliveira G, Peñuelas J. Effects of winter cold stress on photosynthesis and photochemical efficiency of PSII of the Mediterranean Cistus albidus L. and Quercus ilex L. Plant Eco. 2005;175(2):179-191.

44. Sheng $M$, Tang $M$, Chen $H$, Yang $B$, Zhang F, Huang $Y$. Influence of arbuscular mycorrhizae on photosynthesis and water status of maize plants under salt stress. Mycorrhiza, 2008;18(6-7):287296.

45. Björkman O, Demmig B. Photon yield of 02 evolution and chlorophyll fluorescence characteristics at $77 \mathrm{~K}$ among vascular plants of diverse origins. Planta. 1987;170(4):489-504.

46. Kalaji HM, Jajoo A, Oukarroum A, Brestic M, Zivcak M, Samborska IA, Centner MD, Łukasik I, Goltsev $\mathrm{V}$, Ladle RJ. Chlorophyll a fluorescence as a tool to monitor physiological status of plants under abiotic stress conditions. Acta physiol plant. 2016;38(4):102.

47. Carvalho LC, Osório ML, Chaves MM, Amâncio S. Chlorophyll fluorescence as an indicator of photosynthetic functioning of in vitro grapevine and chestnut plantlets under ex vitro acclimatization. Plant Cell Tiss Org. 2001;67(3):271-280.

48. Miyata K, Noguchi K, Terashima I. Cost and benefit of the repair of photodamaged photosystem II in spinach leaves: roles of acclimation to growth light. Photosynth Res. 2012;113(1-3):165-180.

49. Shah AN, Yang G, Tanveer M, lqbal J. Leaf gas exchange, source-sink relationship, and growth response of cotton to the interactive effects of nitrogen rate and planting density. Acta Physiol Plant. 2017;39(5):119.

50. Niu Y, Chen G, Peng DL, Song B, Yang Y, Li ZM, Sun H. Grey leaves in an alpine plant: a cryptic colouration to avoid attack?. New Phytologist. 2014;203(3):953-963.

51. Inskeep WP, Bloom PR. Extinction coefficients of chlorophyll a and b in N, N-dimethylformamide and $80 \%$ acetone. Plant physiology. 1985;77(2):483-485.

52. Bao SD. Soil and agricultural chemistry analysis, 3rd edn. China Agriculture Press, Beijing. 2000.

53. Fan H, Wu J, Liu W, Yuan Y, Hu L, Cai Q. Linkages of plant and soil C: N: P stoichiometry and their relationships to forest growth in subtropical plantations. Plant Soil. 2015; 392(1-2):127-138.

54. Redondo-Gómez S, Wharmby C, Castillo JM, Mateos-Naranjo E, Luque CJ, Cires AD, Luque T, Davy AJ, Figueroa ME. Growth and photosynthetic responses to salinity in an extreme halophyte, Sarcocornia fruticosa. Physiol Plantarum. 2006;128(1):116-124.

55. Ware MA, Belgio E, Ruban AV. Photoprotective capacity of non-photochemical quenching in plants acclimated to different light intensities. Photosynth Res. 2015;126(2-3):261-274.

56. Lima CS, Ferreira-Silva SL, Carvalho FEL, Neto MCL, Aragāo RM, Silva EN, Sousa RMJ, Silveira JAG. Antioxidant protection and PSII regulation mitigate photo-oxidative stress induced by drought followed by high light in cashew plants. Environ Exp Bot. 2018;149:59-69. 
57. Ye ZP. A new model for relationship between irradiance and the rate of photosynthesis in Oryza sativa. Photosynthetica. 2007;45(4):637-640.

58. Liu N, Liu S, Gan Y, Zhang Q, Wang X, Liu S, Dai J. Evaluation of mercury resistance and accumulation characteristics in wheat using a modified membership function. Ecol Indic. 2017;78:292-300.

\section{Tables}

Table 1 Chlorophyll contents (mean \pm S.E.) of three Buddleja species.

\begin{tabular}{ccccc}
\hline Species & $\begin{array}{c}\text { Chlorophyll a }\left(\mathrm{mg} \bullet \mathrm{g}^{-}\right. \\
1 \mathrm{n})\end{array}$ & $\begin{array}{c}\text { Chlorophyll b }\left(\mathrm{mg} \bullet \mathrm{g}^{-}\right. \\
1 \text { ) }\end{array}$ & Total Chlorophyll $\left(\mathrm{mg} \bullet \mathrm{g}^{-1}\right)$ & Chlorophyll a/b \\
\hline B. crispa & $6.28 \pm 0.23 \mathrm{~b}$ & $1.74 \pm 0.11 \mathrm{~b}$ & $8.02 \pm 0.34 \mathrm{bc}$ & $3.61 \pm 0.11 \mathrm{a}$ \\
\hline F1 hybrids & $8.02 \pm 0.26 \mathrm{a}$ & $2.16 \pm 0.10 \mathrm{a}$ & $10.41 \pm 0.56 \mathrm{a}$ & $3.72 \pm 0.09 \mathrm{a}$ \\
\hline $\begin{array}{c}\text { B. } \\
\text { officinalis }\end{array}$ & $2.87 \pm 0.30 \mathrm{c}$ & $3.33 \pm 0.49 \mathrm{a}$ & $6.2 \pm 0.39 \mathrm{c}$ & $0.93 \pm 0.24 \mathrm{~b}$ \\
\hline
\end{tabular}

Table 2 Fitting parameters of PAR-Pn response curves (mean \pm S.E.) of three Buddleja species.

\begin{tabular}{|c|c|c|c|c|c|}
\hline Species & $\begin{array}{c}\mathrm{AQY} \\
\left(\mathrm{mmol} \mathrm{CO} 2 \cdot \mathrm{mmol}^{-1}\right. \\
\text { photo })\end{array}$ & $\begin{array}{c}\text { Pmax } \\
\left(\mu \mathrm{mol} \mathrm{CO}_{2} \cdot \mathrm{m}^{-}\right. \\
\left.2 \cdot \mathrm{s}^{-1}\right)\end{array}$ & $\begin{array}{c}\text { LSP } \\
\left(\mathrm{mmol} \text { photon } \cdot \mathrm{m}^{-}\right. \\
\left.2 \cdot \mathrm{s}^{-1}\right)\end{array}$ & $\begin{array}{c}\text { LCP } \\
\left(\mathrm{mmol} \text { photon } \cdot \mathrm{m}^{-}\right. \\
\left.{ }^{2} \cdot \mathrm{s}^{-1}\right)\end{array}$ & $\begin{array}{c}\mathrm{Rd} \\
\left(\mathrm{mmol} \mathrm{CO} 2 \cdot \mathrm{m}^{-}\right. \\
\left.2 \cdot \mathrm{s}^{-11}\right)\end{array}$ \\
\hline B. crispa & $0.08 \pm 0.01 \mathrm{a}$ & $13.32 \pm 0.43 a$ & $\begin{array}{c}1098.89 \pm \\
27.77 \mathrm{a}\end{array}$ & $24.82 \pm 2.21 \mathrm{a}$ & $1.79 \pm 0.25 a$ \\
\hline $\begin{array}{c}\text { F1 } \\
\text { hybrids }\end{array}$ & $0.06 \pm 0.001 b$ & $9.19 \pm 0.41 b$ & $\begin{array}{c}1050.61 \pm \\
58.72 \mathrm{a}\end{array}$ & $23.31 \pm 1.32 \mathrm{a}$ & $1.14 \pm 0.05 b$ \\
\hline $\begin{array}{c}B . \\
\text { officinalis }\end{array}$ & $0.08 \pm 0.01 \mathrm{a}$ & $\begin{array}{c}10.59 \pm \\
0.81 \mathrm{~b}\end{array}$ & $963.83 \pm 81.23 a$ & $24.73 \pm 2.92 \mathrm{a}$ & $1.83 \pm 0.16 a$ \\
\hline
\end{tabular}

Table 3 The membership function values (mean \pm S.E.) of three Buddleja species based on all investigated traits. 


\begin{tabular}{ccccc}
\hline Species & $u X j$ & $\square \mathrm{W} j$ & $\mathrm{D}$ & \\
& & & & Comprehensive comparison \\
\hline B. crispa & $0.53 \pm 0.02$ & $10.39 \pm 2.34$ & 179.23 & 1 \\
\hline F1 hybrids & $0.52 \pm 0.02$ & $6.30 \pm 1.99$ & 83.14 & 2 \\
\hline B. officinalis & $0.50 \pm 0.02$ & $1.72 \pm 0.49$ & 29.25 & 3 \\
\hline
\end{tabular}

Figures
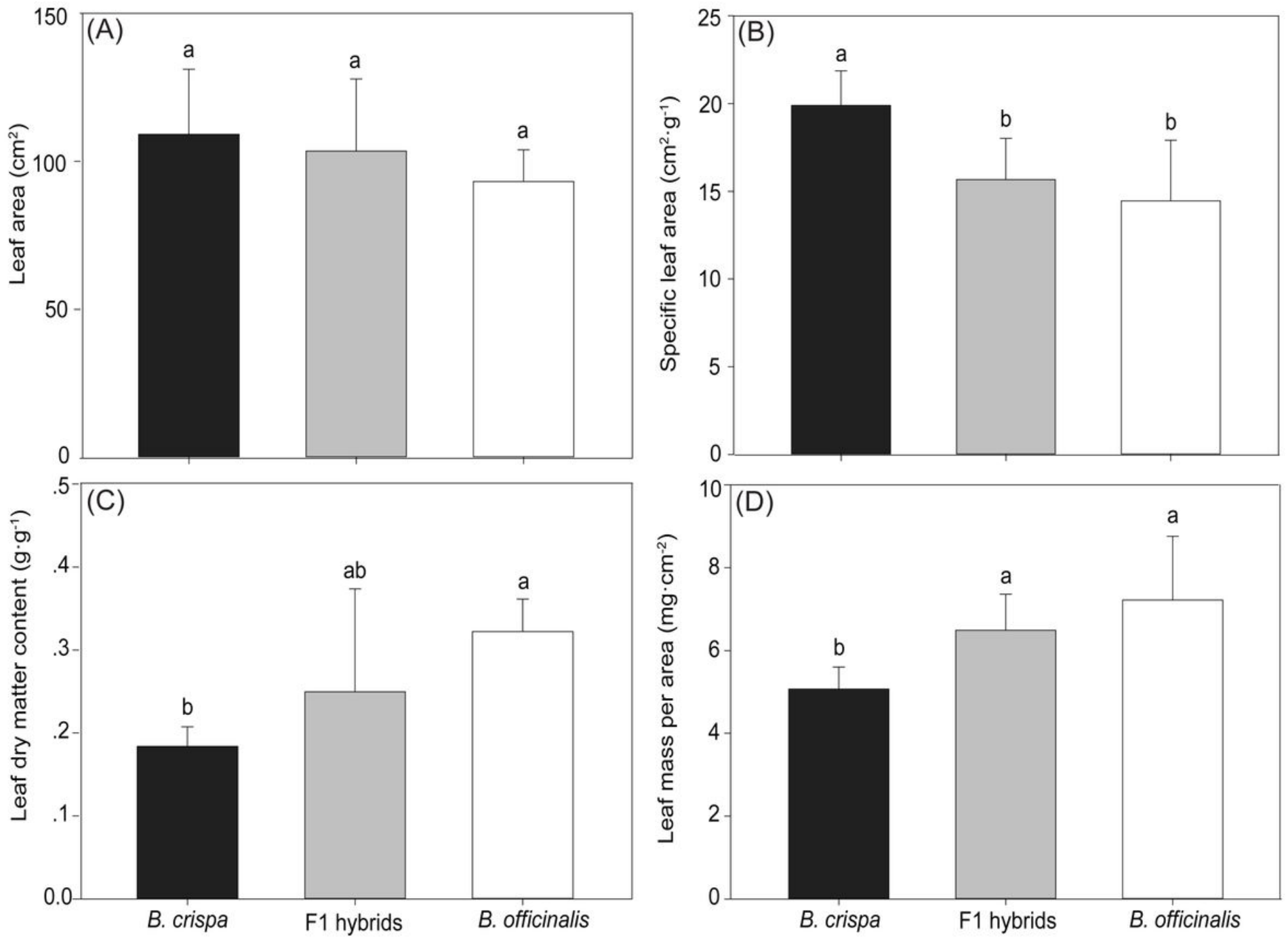

Figure 1

Leaf growth characteristics of three Buddleja species. (A) Leaf area (LA); (B) Specific leaf area (SLA); (C) Leaf dry matter content (LDMC); (D) Leaf mass per area (LMA). 

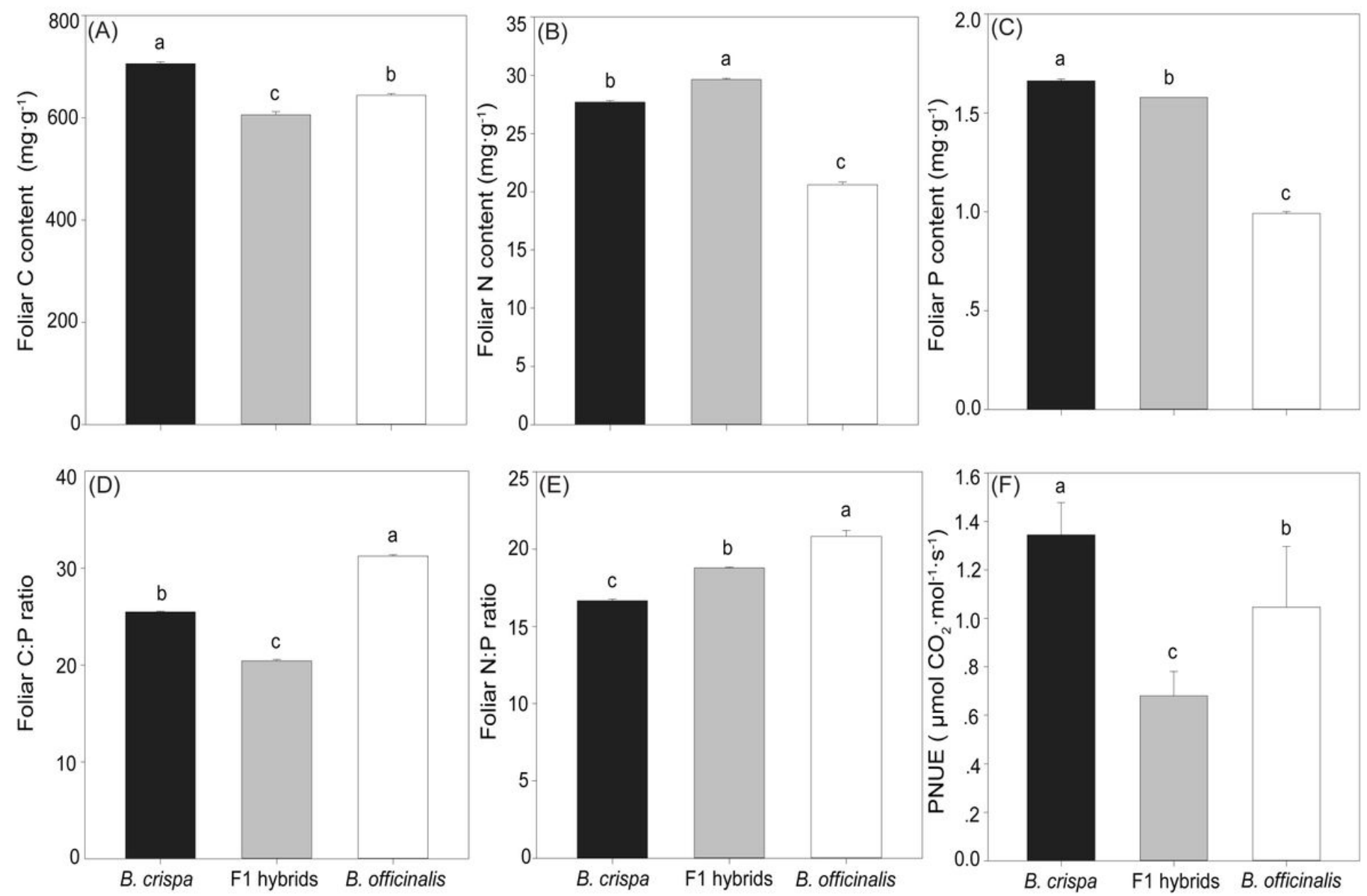

Figure 2

Leaf C, N, P stoichiometry of three Buddleja species. (A) Foliar C content; (B) Foliar N content; (C) Foliar P content; (D) Foliar C:P ratio; (E) Foliar N:P ratio; (F) PNUE. 

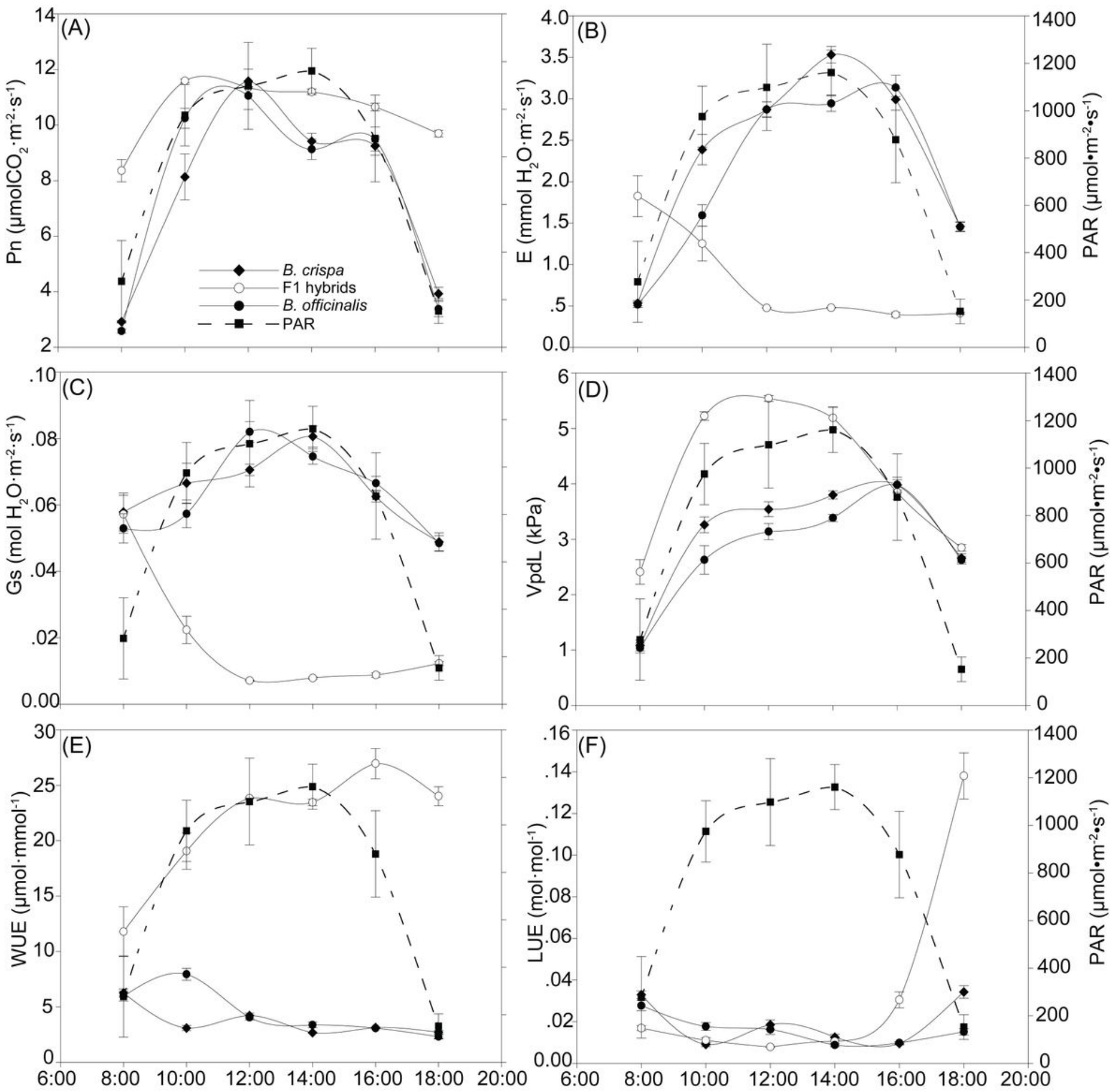

Day of time

\section{Figure 3}

Photosynthetic diurnal variation in gas exchange of three Buddleja species. (A) Pn; (B) E; (C) Gs; (D) VpdL; (E) WUE; (F) LUE. 

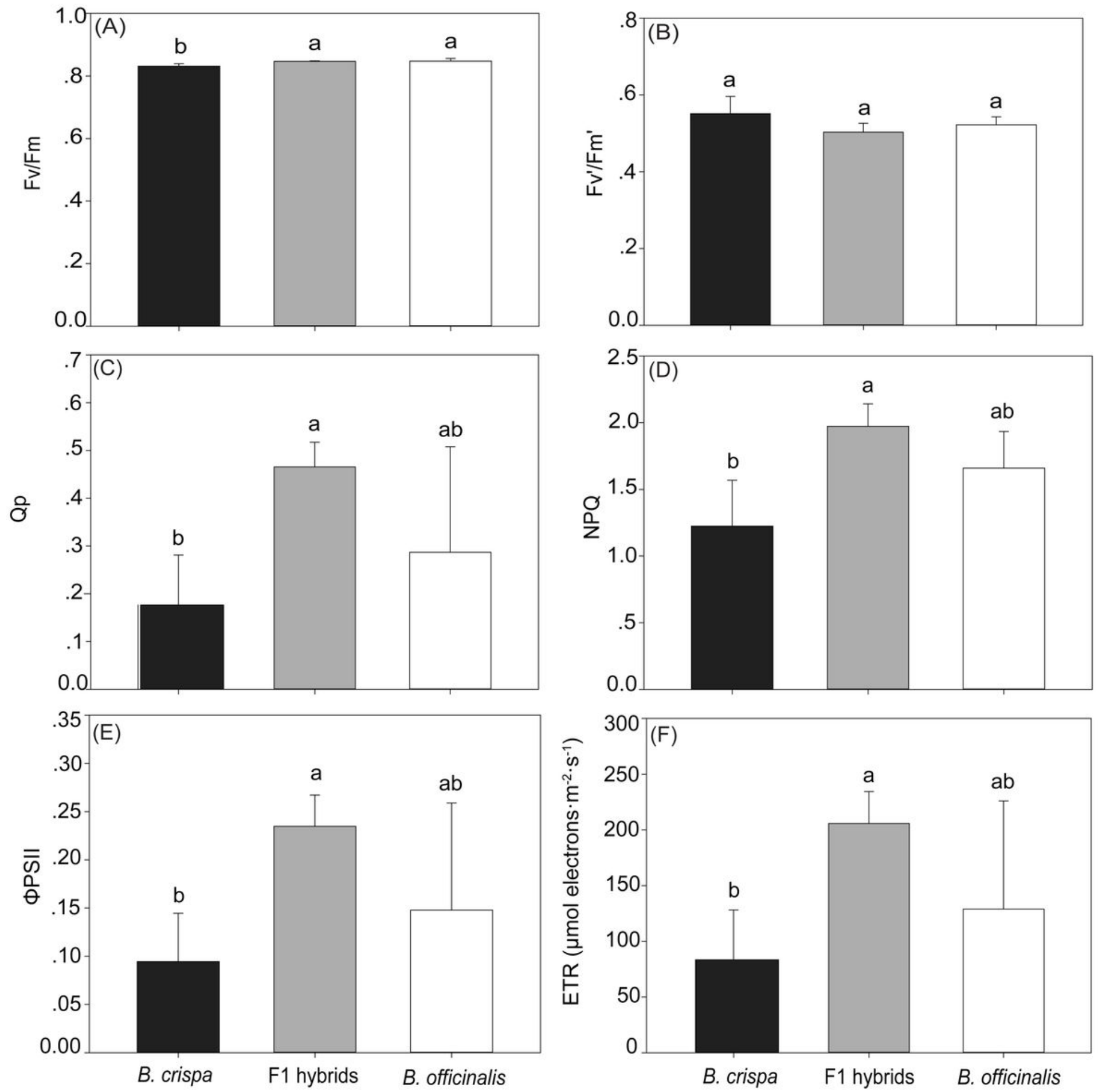

Figure 4

Chlorophyll a fluorescence characteristics of three Buddleja species. (A) Fv/Fm; (B) Fv'/Fm'; (C) Qp; (D) NPQ; (E) ФPSII; (F) ETR. 


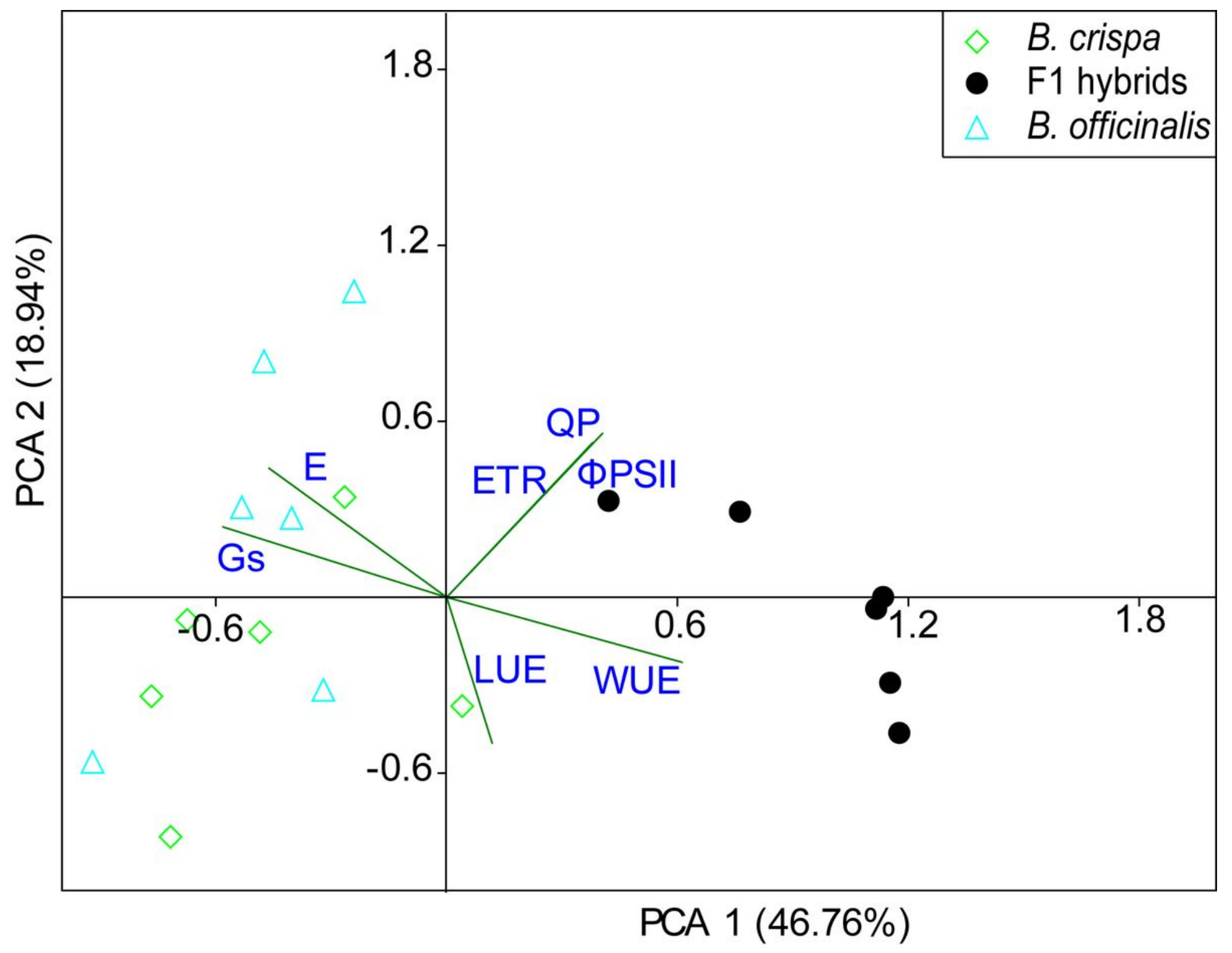

Figure 5

PCA (Principal Component Analysis) biplot based on plant growth, gas-exchange and chlorophyll a fluorescence characteristics of three Buddleja species. 

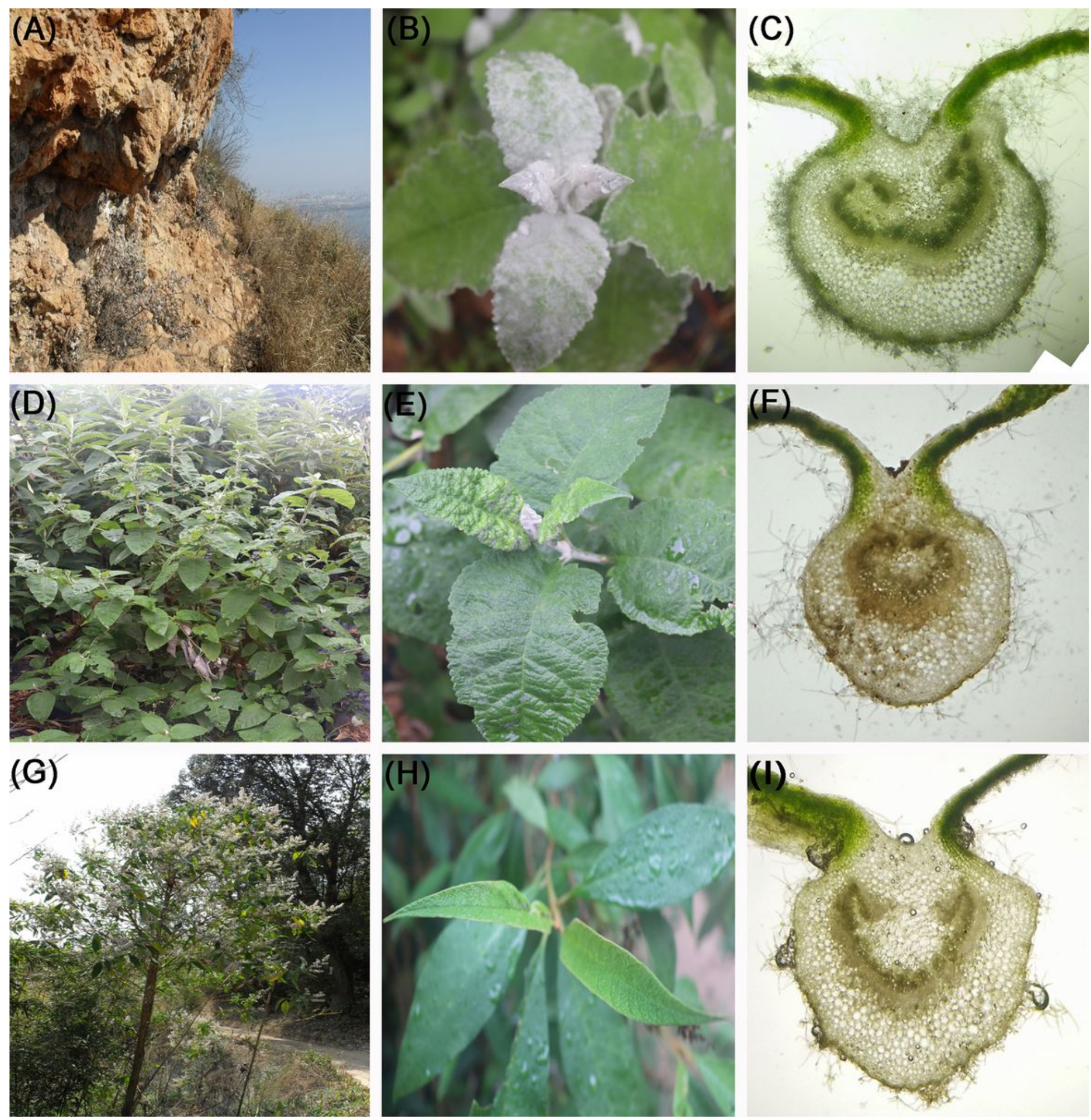

\section{Figure 6}

Plant habitats $(A, D, G)$, leaf morphologies $(B, E, H)$ and leaf anatomical structures $(C, F, I)$ of $B$. crispa $(A$, $B, C), F 1$ hybrids $(D, E, F)$, and $B$. officinalis $(G, H, I)$. 